\title{
Effect of genetic background on the stability of sunflower fatty acid composition in different high oleic mutations
}

Running title: Genetic background effect on sunflower high oleic oil composition

\begin{abstract}
Constanza Alberio ${ }^{\mathrm{ab}}$, Luis A. N. Aguirrezábal ${ }^{\mathrm{ab}}$, Natalia G. Izquierdo ${ }^{\mathrm{ab}}$, Roberto Reid ${ }^{\mathrm{d}}$, Sebastián Zuil ${ }^{\mathrm{C}}$, Andrés Zambelli ${ }^{\mathrm{e} *}$

a Comisión Nacional de Investigaciones Científicas y Técnicas (CONICET), Argentina.

${ }^{\mathrm{b}}$ Laboratorio de Fisiología Vegetal, Facultad de Ciencias Agrarias, Universidad Nacional de Mar del Plata (FCA-UNMdP), Ruta 226 Km 73.5, 7620 Balcarce, Argentina.

c Instituto Nacional de Tecnología Agropecuaria, INTA, Ruta $11 \mathrm{Km} \mathrm{773,} 3560$
\end{abstract} Reconquista, Argentina.

d Centro de Investigación en Biotecnología, Advanta Semillas, Ruta 226 Km 60.5, Balcarce, Argentina.

e Departamento de Ciencias Básicas, Facultad de Ciencias Agrarias, Universidad Nacional de Mar del Plata (FCA-UNMdP), Ruta 226 Km 73.5, 7620 Balcarce, Argentina.

${ }^{*}$ Correspondence to: A. Zambelli, Departamento de Ciencias Básicas, Facultad de

Ciencias Agrarias, Universidad Nacional de Mar del Plata (FCA-UNMdP). E-mail:

andres.zambelli@mdp.edu.ar Phone: +54 2266439100

\section{ABSTRACT}

BACKGROUND: The effect of genetic background on the stability of fatty acid composition in sunflower near isogenic lines (NILs) carrying high oleic Pervenets (P) or high oleic NM1 mutations was studied. The materials were field-tested in different locations and sowing dates to evaluate a wide range of environmental conditions.

This article has been accepted for publication and undergone full peer review but has not been through the copyediting, typesetting, pagination and proofreading process, which may lead to differences between this version and the Version of Record. Please cite this article as doi: $10.1002 /$ jsfa.8924 
Relationships between the fatty acids and the minimum night temperature (MNT) were established and the response was characterized.

RESULTS: Genetic background effect for the fatty acid composition was found in both groups of NILs. NM1-NILs showed an oleic level higher than $910 \mathrm{~g} \mathrm{~kg}^{-1}$ and they were more stable across environments with a null or low dependence from the genetic background; contrarily, high oleic materials bearing the $\mathrm{P}$ mutation showed lower levels of oleic acid, with a higher variation in fatty acid composition and a highly significant dependence with the genetic background.

CONCLUSION: NM1 mutation is the best option to develop ultra-high oleic sunflower oil stable across environments and genetic backgrounds, making its agronomical production more efficient and predictable.

Key Words: Helianthus annuus; genetic background; high oleic oilseed; near isogenic lines; environment

\section{INTRODUCTION}

Sunflower (Helianthus annuus L.) is one of the most important oilseed crops in the world due to the high quality of its oil. For several food applications, oils with a high content of monounsaturated fatty acid and a low polyunsaturated fatty acid content are required. Thus, high oleic sunflower is one of the most used and valued oils by the market due to its characteristics: extended fry- and shelf-life, better operative efficiency and health benefits for consumers. ${ }^{1,2}$ Therefore, some of the current goals in sunflower breeding is to develop superior high oleic materials (oilseed with at least $800 \mathrm{~g} \mathrm{~kg}^{-1}$ of oleic acid) and ultra-high oleic materials (oleic acid higher than $910 \mathrm{~g} \mathrm{~kg}^{-1}$ and linoleic acid lower than $20 \mathrm{~g} \mathrm{~kg}^{-1}$ ).,4 The inheritance of quantitative traits has been described as a "moving target" since it is affected not only by the actions of multiple individual genes, but also by the interactions 
between genes (epistasis) and between genes and environmental factors. When quantitative trait loci (QTL) are characterized in one genetic background or environment, they may behave differently as these factors are altered. ${ }^{5}$ Genetic background comprises the pool of genes determining the characteristics of each genotype, which in turn can interact with the high oleic Pervenets $(P)$ mutation. ${ }^{6}$ Not every sunflower genotype carrying the $\mathrm{P}$ mutation may express the high oleic phenotype in any genetic background. Thus, genetic background may be an important factor in developing mutants not only for oleic acid, but also for other fatty acids, such as stearic. ${ }^{6}$

In molecular breeding it is important to work with a specific population that more efficiently allows to identify the genes associated with the QTL or trait of interest. The development and use of near isogenic lines (NILs) differing only in the trait of interest ${ }^{7,8}$ provide a useful tool for studying the effects of a particular QTL on the plant behavior. NILs vary only in the alleles responsible for the characteristic of interest and are identical for the remaining alleles. ${ }^{9}$ Therefore, the use of NILs is proper to assess the interaction of a particular genetic background with different allelic variants of the trait of interest and the environment.

Mutations induced in different genes conferring some traits of agronomic and commercial interest (such as oilseed composition and herbicide resistance) have been developed in sunflower; specifically, mutations on microsomal oleate desaturase, fad2-1 gene, gave rise to sunflower high oleic mutants Pervenets and 29066, among others. ${ }^{10}$

Several environmental factors were described as responsible for fatty acid composition changes. However, temperature was reported as its main environmental modulator. ${ }^{11-22}$ Therefore, when assessing changes in sunflower fatty acid composition, environmental variations is caused mostly by temperature. In this sense, previous work reported that a sunflower NIL carrying the new high oleic mutation 29066 (named NM1) showed higher fatty acid stability and ultra-high oleic quality across environments, compared to the 
respective sunflower $\mathrm{P}-\mathrm{NIL}{ }^{23}$ Although a possible effect of genetic background on the oleic acid content after changes of minimum night temperature (MNT) was documented in traditional sunflower hybrids ${ }^{24}$ and in high oleic sunflower hybrids carrying the $\mathrm{P}$ mutation, ${ }^{22}$ this effect was not empirically proved in NILs carrying the $P$ or the NM1 mutation. Likewise, genetic background effect on NILs carrying these mutations was neither been tested. This knowledge can be considered of agronomic and economic importance. Indeed, if a genetic background effect is evidenced, the best genetic background could potentially be selected to produce oils with an improved quality. If not, the range of genotype selection possibilities would be much larger, allowing developing high oleic oils with no restriction to particular genotypes, focusing on the type of mutation. This would also allow breeders to choose the best genotypes adapted to specific environments in order to obtain the highest oleic acid potential. So, breeders could work on a specific character of interest with a stable genetic basis.

The aim of this work was to test in the field the effect of the genetic background on the stability of the fatty acid composition across environments in NILs carrying the NM1 or the $\mathrm{P}$ high oleic mutations under a wide range of temperatures conditions.

\section{MATERIALS AND METHODS}

\section{Plant material and description}

Four pairs of NILs carrying the high oleic P and NM1 (29066) mutations were tested in the field. Each pair of NILs represented four elite genetic backgrounds, called GB1, GB2, GB3 and GB4 (Table 1). Plant materials were provided by Advanta Semillas S.A.I.C.

Table 1. The NILs included in this study were coded with a letter indicating the carrying high oleic mutation (P: Pervenets; NM1: 29066) and a number indicating the respective genetic background (GB1-GB4).

\begin{tabular}{lll}
\hline NIL & Genetic
\end{tabular}




\begin{tabular}{lcc}
\hline & background & mutation \\
\hline P-1 & GB1 & P \\
NM1-1 & GB1 & NM1 \\
P-2 & GB2 & P \\
NM1-2 & GB2 & NM1 \\
P-3 & GB3 & P \\
NM1-3 & GB3 & NM1 \\
P-4 & GB4 & P \\
NM1-4 & GB4 & NM1 \\
\hline
\end{tabular}

The high oleic NILs were developed by backcrossing different traditional elite genotypes with a line carrying the $\mathrm{P}$ or the NM1 mutation. After three generations of backcrossing the resulting genotypes were inbred by at least six successive self-pollinated generations. In order to evaluate the relationship among the different $\mathrm{P}$ and NM1 NILs, a pairwise comparison was done by genotyping using a set of 276 SNP markers equally distributed across the sunflower genome $(p<0.0001)$. Pairwise genetic distance matrix was constructed based on similarity coefficients calculated from SNP allele sharing. This analysis showed, as expected, a close genetic relationship among NIL pairs carrying the two different high oleic mutations with similarities ranging from 0.93 to 0.99 . When different genetic backgrounds were compared similarities ranged from 0.52 to 0.78 (Table 2).

Table 2. Pairwise genetic distance matrix based on similarity coefficients between $P$ and NM1 NILs.

\begin{tabular}{ccccccccc}
\hline GENOTYPE & P-1 & P-2 & P-3 & P-4 & NM1-1 & NM1-2 & NM1-3 & NM1-4 \\
\hline P-1 & 1 & 0.62 & 0.66 & 0.58 & $\mathbf{0 . 9 3}$ & 0.62 & 0.66 & 0.58 \\
P-2 & & 1 & 0.77 & 0.59 & 0.64 & $\mathbf{0 . 9 9}$ & 0.77 & 0.6 \\
P-3 & & & 1 & 0.52 & 0.69 & 0.78 & $\mathbf{0 . 9 8}$ & 0.52 \\
P-4 & & & & 1 & 0.61 & 0.59 & 0.54 & $\mathbf{0 . 9 6}$ \\
NM1-1 & & & & & 1 & 0.64 & 0.7 & 0.61 \\
NM1-2 & & & & & & 1 & 0.78 & 0.59 \\
NM1-3 & & & & & & & 1 & 0.524 \\
NM1-4 & & & & & & & & 1 \\
\hline
\end{tabular}

This article is protected by copyright. All rights reserved. 


\section{Field experiments}

NILs were tested in five field experiments conducted in three different environments of Argentina: Balcarce (B1, B2, and B3), Venado Tuerto (VT) and Reconquista (R) (Table 3). B1, B2, and B3 were sown in different sowing dates. Sowing was done manually using a complete randomized blocks design with two replicates. Each plot consisted of five rows, 4 $\mathrm{m}$ in length and spaced $0.7 \mathrm{~m}$ between rows. The plant density was 6.5 plants per $\mathrm{m}^{2}$. Flowering time of a plot was registered when $95 \%$ of the plants were at R5.1 stage. ${ }^{25}$ Before flowering each capitula was bagged to ensure self-pollination. Ten plants per plot were harvested at physiological maturity, determined by the brown color of bracts in the capitula. $^{26}$

Air temperature in Balcarce (B1, B2 and B3) was measured with copper-constantan thermocouples (Termoquar, Buenos Aires, Argentina) located $1.2 \mathrm{~m}$ above the soil and registered with data loggers (Cavadevices, Buenos Aires, Argentina). Air temperature from VT and R were obtained from meteorological stations, placed near the field experiments ( $\leq$ $200 \mathrm{~m}$ ). Air temperature was used to calculate the minimum night temperature (MNT) during the 100 to 300 ddaf (degree-days after flowering) period, identified as the best predictor of the oleic acid percentage. ${ }^{17}$

In all experiments water availability was supplemented by irrigation. Pest and disease control were applied as needed. Nutrient availability was measured by collecting soil samples from two depths, $0-20 \mathrm{~cm}$ and $20-40 \mathrm{~cm}$. Organic matter was measured through oxidation using the chromic acid method. ${ }^{27}$ Nitrate was determined according to Echeverría et al. ${ }^{28}$ and available phosphorous (P-Bray) was determined according to Bray and Kurtz. ${ }^{29}$ Concentration of $\mathrm{N}$ and $\mathrm{P}$ concentration were adequate for normal development of sunflower plants in all locations and growing seasons. ${ }^{30}$ Field data corresponding to the NILs from GB1 were taken from Alberio et al. ${ }^{23}$ and compared with the additional genetic backgrounds included in this paper. 


\section{Sample and data analysis}

Oil extraction and methylation were performed according to Ruiz-López et al.. ${ }^{31}$ Oilseed fatty acid composition from each genotype was determined by gas-liquid chromatography with an Agilent 6890 gas chromatograph with FID detector (Agilent Technologies Inc., Palo Alto, CA, USA). Methylated fatty acid were separated by using a Supelco SP-2380 fused silica capillary column (30 m length, $0.25 \mathrm{~mm}$ i.d., $0.20 \mathrm{~mm}$ film thickness: Bellefonte, PA, USA). The carrier was gas hydrogen at $28 \mathrm{~cm} \mathrm{~s}^{-1}$. The detector and injector temperature was $200^{\circ} \mathrm{C}$, and the oven temperature was kept at $170{ }^{\circ} \mathrm{C}$.

Fatty acid composition data were analyzed by using multifactorial and variance procedures included in Infostat Statistical Software. ${ }^{32}$ Residuals of fatty acids contents were homogeneously distributed around zero (0) so data were not transformed. When statistical differences were detected among genotypes or locations the highest $p$ value was presented. Treatment means were compared by Tukey test $(p<0.05)$. The different fatty acids concentrations were related to temperature using linear regression. Minimum night temperature (MNT) during the 100 to 300 ddaf was used as independent variable to analyze the variations in oleic acid concentration in the sunflower genotypes, using a base temperature of $6{ }^{\circ} \mathrm{C} .{ }^{33}$

Table 3. Location, identification of the experiments (ID), latitude ( ${ }^{\circ} \mathrm{S}$ ), genotypes, sowing dates, flowering dates (R5.1 stage), mean of minimum night temperatures (MNT) during the 100-300 ddaf period (base temperature: $6^{\circ} \mathrm{C}$ ) and soil characteristics (from samples collected at $20 \mathrm{~cm}$ depth) at field experimental sites. 


\begin{tabular}{|c|c|c|c|c|c|c|c|}
\hline LOCATION & ID & $\begin{array}{l}\text { LATITUDE } \\
{ }^{\circ} \mathrm{S}\end{array}$ & $\begin{array}{l}\text { SOWING } \\
\text { DATE }\end{array}$ & GENOTYPE* & $\begin{array}{l}\text { FLOWERING } \\
\text { DATE (R5.1) }\end{array}$ & $\begin{array}{c}\text { MNT } \\
\text { 100-300 DDAF } \\
\left({ }^{\circ} \mathrm{C}\right) \\
\end{array}$ & $\begin{array}{l}\text { TYPE OF } \\
\text { SOIL }\end{array}$ \\
\hline \multirow{9}{*}{ Reconquista } & \multirow{8}{*}{ R2 } & \multirow{8}{*}{29} & \multirow{8}{*}{ 09/05/13 } & $\mathrm{P}-1$ & $11 / 22 / 13$ & 19.4 & \multirow{8}{*}{$\begin{array}{l}\text { Aquic } \\
\text { Argiudol }\end{array}$} \\
\hline & & & & P-2 & $11 / 29 / 13$ & 19.9 & \\
\hline & & & & P-3 & $12 / 02 / 13$ & 19.8 & \\
\hline & & & & P-4 & $11 / 26 / 13$ & 20.4 & \\
\hline & & & & NM1-1 & $11 / 26 / 13$ & 20.4 & \\
\hline & & & & NM1-2 & $11 / 29 / 13$ & 19.9 & \\
\hline & & & & NM1-3 & $11 / 29 / 13$ & 19.9 & \\
\hline & & & & NM1-4 & $12 / 02 / 13$ & 19.8 & \\
\hline & \multirow{8}{*}{ VT2 } & \multirow{8}{*}{33} & \multirow{8}{*}{$10 / 14 / 13$} & $P-1$ & $12 / 23 / 13$ & 20.2 & \multirow{8}{*}{$\begin{array}{l}\text { Typic } \\
\text { Argiudol }\end{array}$} \\
\hline \multirow{7}{*}{ Venado Tuerto } & & & & P-2 & $12 / 27 / 13$ & 18.8 & \\
\hline & & & & P-3 & $12 / 26 / 13$ & 19.1 & \\
\hline & & & & $\mathrm{P}-4$ & $12 / 25 / 13$ & 19.6 & \\
\hline & & & & NM1-1 & $12 / 23 / 13$ & 20.2 & \\
\hline & & & & NM1-2 & $12 / 27 / 13$ & 18.8 & \\
\hline & & & & NM1-3 & $12 / 26 / 13$ & 19.1 & \\
\hline & & & & NM1-4 & $12 / 29 / 13$ & 17.3 & \\
\hline \multirow{8}{*}{ Balcarce } & \multirow{8}{*}{ B1 } & \multirow{8}{*}{37} & \multirow{8}{*}{$10 / 15 / 13$} & $P-1$ & $01 / 08 / 14$ & 15.9 & \multirow{8}{*}{$\begin{array}{l}\text { Typic } \\
\text { Argiudol }\end{array}$} \\
\hline & & & & P-2 & $01 / 12 / 14$ & 16.1 & \\
\hline & & & & P-3 & $01 / 11 / 14$ & 16.1 & \\
\hline & & & & P-4 & $01 / 14 / 13$ & 16.1 & \\
\hline & & & & NM1-1 & 01/10/14 & 16.2 & \\
\hline & & & & NM1-2 & $01 / 11 / 14$ & 16.1 & \\
\hline & & & & NM1-3 & 01/10/14 & 15.7 & \\
\hline & & & & NM1-4 & $01 / 15 / 14$ & 16.0 & \\
\hline \multirow{8}{*}{ Balcarce } & \multirow{8}{*}{ B2 } & \multirow{8}{*}{37} & \multirow{8}{*}{$11 / 05 / 13$} & $P-1$ & $01 / 20 / 14$ & 16.7 & \multirow{8}{*}{$\begin{array}{l}\text { Typic } \\
\text { Argiudol }\end{array}$} \\
\hline & & & & P-2 & $01 / 14 / 14$ & 16.1 & \\
\hline & & & & P-3 & 01/16/14 & 15.9 & \\
\hline & & & & P-4 & $01 / 23 / 14$ & 16.2 & \\
\hline & & & & NM1-1 & $01 / 20 / 14$ & 16.8 & \\
\hline & & & & NM1-2 & $01 / 16 / 14$ & 15.9 & \\
\hline & & & & NM1-3 & $01 / 16 / 14$ & 15.9 & \\
\hline & & & & NM1-4 & $01 / 23 / 14$ & 16.3 & \\
\hline \multirow{8}{*}{ Balcarce } & \multirow{8}{*}{ B3 } & \multirow{8}{*}{37} & \multirow{8}{*}{$12 / 09 / 13$} & $P-1$ & $02 / 11 / 14$ & 12.5 & \\
\hline & & & & P-2 & $02 / 10 / 14$ & 13.6 & \\
\hline & & & & P-3 & $02 / 11 / 14$ & 13.4 & \\
\hline & & & & P-4 & $02 / 11 / 14$ & 13.4 & Typic \\
\hline & & & & NM1-1 & $02 / 13 / 14$ & 12.4 & Argiudol \\
\hline & & & & NM1-2 & $02 / 11 / 14$ & 13.6 & \\
\hline & & & & NM1-3 & $02 / 11 / 14$ & 13.4 & \\
\hline & & & & NM1-4 & $02 / 11 / 14$ & 13.4 & \\
\hline
\end{tabular}

* Data from P-1 and NM1-1 were taken from Alberio et al. ${ }^{23}$ and were reanalized to be compared with the other genetic backgrounds.

No differences in the MNT were observed between replicates in each location and sowing dates $(p<$ 0.05).

This article is protected by copyright. All rights reserved. 


\section{RESULTS}

\section{Genotype by environment interactions}

A triple interaction between mutation - genetic background - environment for the oleic and linoleic fatty acids was observed, while saturated fatty acids were influenced by the interaction between genetic background and the high oleic mutation or the genetic background and the environment (Table 4).

Data analysis grouping all genetic backgrounds for each high oleic mutation highlighted that the highest variability for unsaturated fatty acids was associated to the type of mutation, while for saturated fatty acids variability was associated with both the mutation and the environment. Genetic background effect was evidenced in the fatty acid composition by analyzing data as single set, and analyzing them separately grouped as $\mathrm{P}$ or NM1-NILs. Thus, the highest variability was detected in the group of PNILs; for the stearic and the oleic acid it was associated with the genetic background, while for palmitic and linoleic acids it was mainly associated with the environment (Table 4). In the group of NM1-NILs, the highest variability for linoleic acid and stearic acid was associated with the genetic background, while for palmitic acid it was associated with the environment. In this group, oleic acid did not show a remarkable variation when compared with the other fatty acids, with the genetic background and the environment contributing equally to the variability (Table 4).

T) ble 4. ANOVA (mean square) of the main fatty acids divided in whole data set, P-NILs and NM1-NILs.

\begin{tabular}{lcccccc}
\hline $\begin{array}{l}\text { Source of } \\
\text { variation }\end{array}$ & DF & Palmitic & Stearic & Oleic & Linoleic & Arachidic \\
\hline Whole data set & & & & & & \\
\hline M & 1 & $0.24 \mathrm{~ns}$ & $168.64^{* * *}$ & $638.85^{* * *}$ & $1235.34^{* * *}$ & $42.67^{* * *}$ \\
GB & 3 & $38.97^{* * *}$ & $149.97^{* * *}$ & $85.12^{* * *}$ & $44.16^{* * *}$ & $66.08^{* * *}$ \\
E & 4 & $184.92^{* * *}$ & $10.55^{* * *}$ & $57.19^{* * *}$ & $333.94^{* * *}$ & $14.46^{* * *}$ \\
GB-M & 3 & $3.22^{*}$ & $19.75^{* * *}$ & $25.29^{* * *}$ & $33.09^{* * *}$ & $2.4 \mathrm{~ns}$ \\
GB-E & 12 & $6.88^{* * *}$ & $11.43^{* * *}$ & $7.85^{* * *}$ & $6.55^{* * *}$ & $9.80^{* * *}$ \\
M-E & 4 & $1.54 \mathrm{~ns}$ & $1.27 \mathrm{~ns}$ & $30.71^{* * *}$ & $131.70^{* * *}$ & $0.82 \mathrm{~ns}$ \\
M-GB-E & 12 & $1.22 \mathrm{~ns}$ & $0.52 \mathrm{~ns}$ & $2.30^{*}$ & $4.70^{* * *}$ & $0.75 \mathrm{~ns}$ \\
Error & 20 & & & & & \\
\hline P-NILs & & & & & & \\
\hline GB & 3 & $22.01^{* * *}$ & $125.31^{* * *}$ & $71.00^{* * *}$ & $15.43^{* * *}$ & $35.44^{* * *}$
\end{tabular}

This article is protected by copyright. All rights reserved. 


\begin{tabular}{lcccccc} 
E & 4 & $70.28^{* * *}$ & $6.01^{* *}$ & $52.69^{* * *}$ & $268.30^{* * *}$ & $3.80^{*}$ \\
GB-E & 12 & $5.04^{* *}$ & $5.71^{* * *}$ & $2.51^{*}$ & $4.49^{* *}$ & $3.86^{* *}$ \\
Error & 20 & & & & & \\
\hline NM1-NILs & & & & & & \\
\hline GB & 3 & $19.89^{* * *}$ & $38.44^{* * *}$ & $22.43^{* * *}$ & $147.28^{* * *}$ & $31.92^{* * *}$ \\
E & 4 & $123.57^{* * *}$ & $5.80^{* *}$ & $25.83^{* * *}$ & $66.58^{* * *}$ & $10.11^{* * *}$ \\
GB-E & 12 & $2.73^{*}$ & $6.28^{* *}$ & $9.49^{* * *}$ & $10.94^{* * *}$ & $9.61^{* * *}$ \\
Error & 20 & & & & & \\
\hline
\end{tabular}

Note: $\mathrm{M}=$ mutation; $\mathrm{GB}=$ genetic background; $\mathrm{E}=$ environment; ${ }^{*},{ }^{* *}$ and ${ }^{* * *}=$ significant at the $p<0.05 ; 0.01 ; 0.001$ levels, respectively. ns= non-significant.

Analyzing each genetic background individually, the mean value of oleic acid content across environments was significantly higher in NM1 group compared with P group (Figure 1). The average of pleic content across environment was highest for GB3 and lowest for GB2 across environments in both groups of NILs (Figure 1). When all genetic backgrounds and environments were analyzed the ninimum oleic acid content in P-NIL group was $871 \mathrm{~g} \mathrm{~kg}^{-1}$, while for NM1-NILs was $907 \mathrm{~g} \mathrm{~kg}^{-1}$. P-NILs presented the highest variability in the response of oleic acid compared to NM1-NILs across environments $\left(\mathrm{CV}_{\text {ENVIRONMENT }}=1.5 \%\right.$ and $C V_{\text {ENVIRONMENT }}=1.0 \%$, respectively $)$ and across genetic ackgrounds $\left(\mathrm{CV}_{\mathrm{GB}}=2.3 \%\right.$ and $\mathrm{CV}_{\mathrm{GB}}=0.9 \%$, respectively $)$.

Linoleic acid content of NM1-NILs differ significantly between genetic backgrounds $(p<0.0001)$, unlike

P-NILs in which any significant differences were registered $(p=0.695)$ (Figure 1). Moreover, most environments differed significantly between $\mathrm{P}$ - and NM1-NILs considering the same genetic background. The lowest linoleic acid content was found in NM1-NILs (less than $26 \mathrm{~g} \mathrm{~kg}^{-1}$ ) (Figure 1).

Variability in the response of saturated fatty acids to genetic background, environment and mutation vas also registered (Table 4). GB2 reached the highest saturated fatty acids values, while GB3 showed he lowest ones in both, $P$ and NM1-NILs (Figure 1). Significant differences in the mean of each saturated fatty acid (palmitic, stearic and arachidic acids) between P- and NM1-NILs from each genetic background were found ( $p<0.01$; data nor shown). Although a genetic background effect in the response of saturated fatty acids was found, the variation across environments and genetic backgrounds was lower when compared to unsaturated fatty acids. For saturated fatty acids, variation 
across environments was higher in NM1-NILs compared to P-NILs $\left(\right.$ CV $_{\text {ENVIRONMENT }}=14.5 \%$ and $\mathrm{CV}_{\text {ENVIRONMENT }}=11.9 \%$, respectively).

GB1
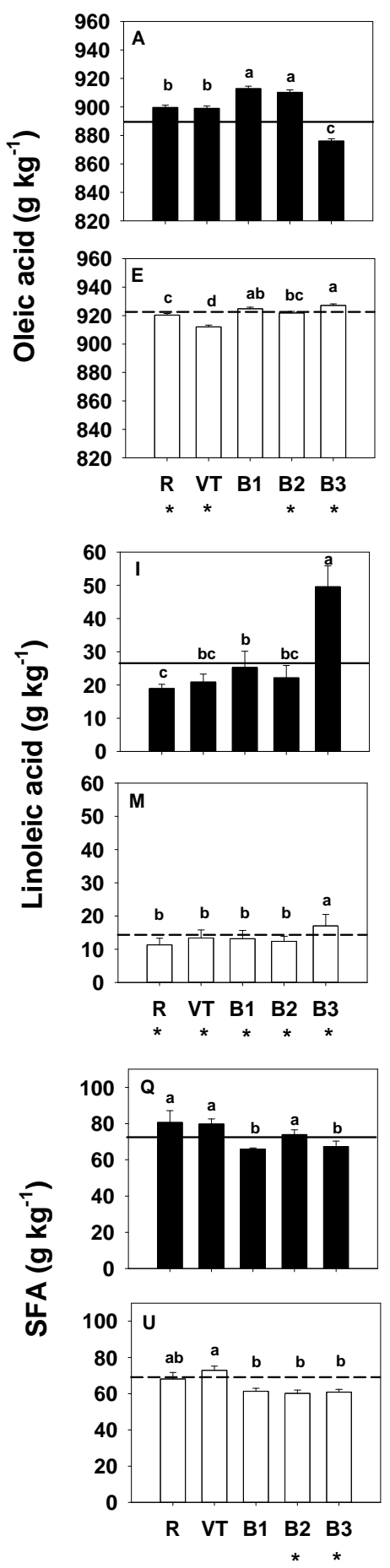

GB2
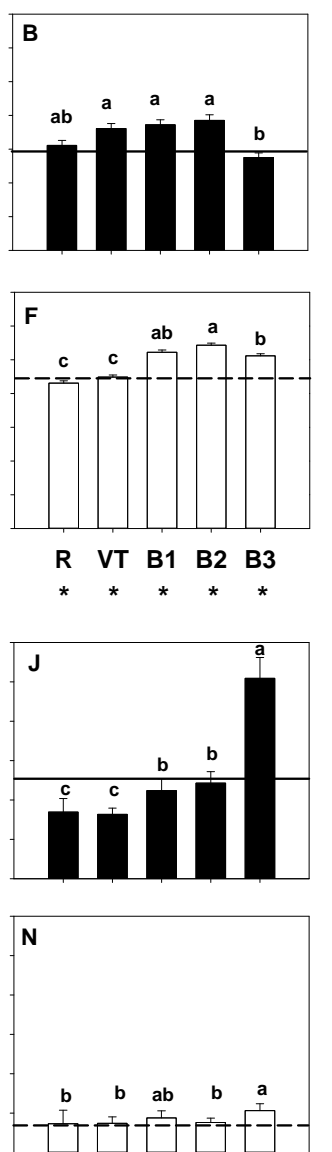

R VT B1 B2 B3
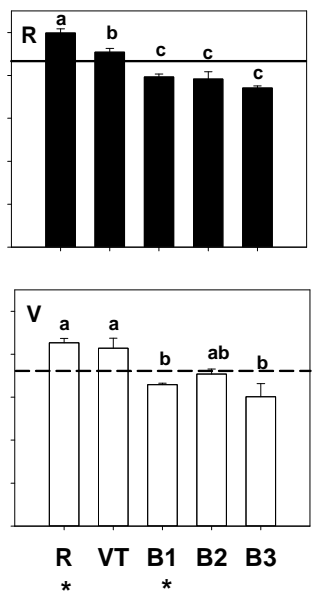

GB3

GB4
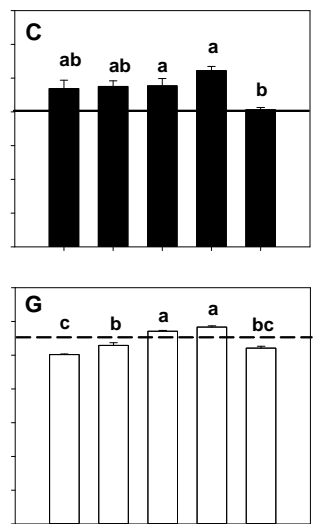

R VT B1 B2 B3
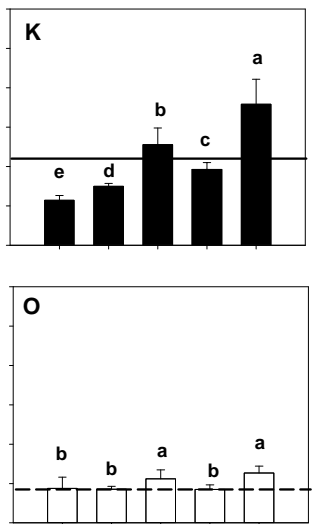

R VT B1 B2 B3
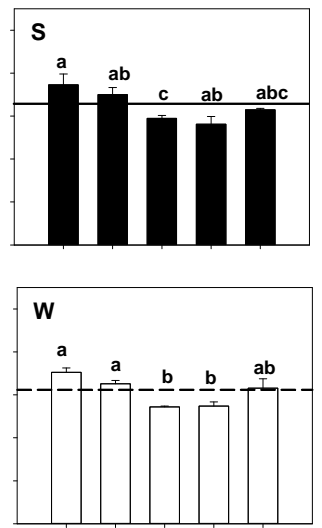

R VT B1 B2 B3
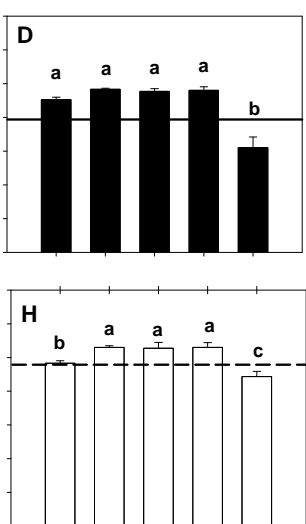

R VT B1 B2 B3
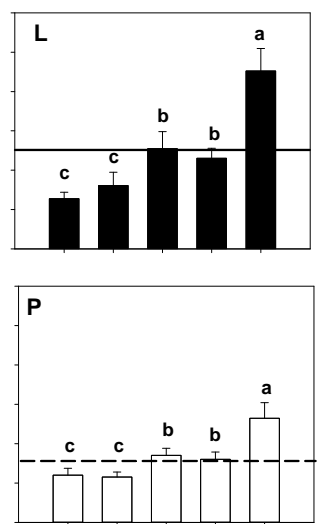

R VT B1 B2 B3
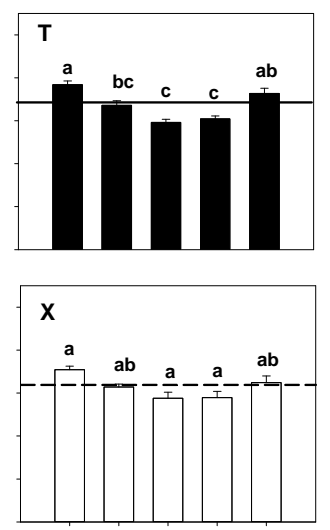

R VT B1 B2 B3

Figure 1. Oleic (A-H: GB1, GB2, GB3 and GB4), linoleic (I-P: GB1, GB2, GB3 and GB4) and saturated fatty acids (SFA) contents (Q-X: GB1, GB2, GB3 and GB4) of sunflower genotypes from four different genetic backgrounds. Each column 
represents the corresponding fatty acid content in P (filled columns) and NM1 NILs (empty columns) in each genetic background and location (R: Reconquista; VT: Venado Tuerto; B1: Balcarce early sowing; B2: Balcarce intermediate sowing; B3: Balcarce late sowing). Solid and dashed lines represent the mean of oleic, linoleic or SFA contents across environments in $\mathrm{P}$ and NM1 NILs, respectively. Letters $(\mathrm{a}-\mathrm{c})$ represent significant differences among environments (ANOVA, $p<0.0001$ ). Asterisks represent significant differences between $P$ and NM1 NILs in each genetic background $(p<0.0001)$. Data are the result of 8-10 plants per block (two replicates) and bars represent the standard error of the mean.

\section{Relationship between fatty acids composition and the MNT}

Genetic background effect in the response of fatty acid composition to MNT in P and NM1-NILs was jdentified $(p<0.0001)$. Analyzing the response of fatty acids across genetic backgrounds in NILs carrying P or NM1 mutation separately allowed to identify a clear positive response to the MNT of the palmitic acid (Figure $2 \mathrm{~A}$, Table A1) and a negative response of the linoleic acid (Figure 2 D, Table A1) in both groups of NILs. A negative trend in the response of the oleic acid to the MNT in NM1-NILs was also observed (Figure $2 \mathrm{C}$, Table A1). No relationship was found in the response of stearic acid to MNT n both groups of NILs.

Oleic acid content remained stable in GB2 and GB3 from P-NILs (Figure $2 \mathrm{~K}$ and O, Table A1) while for within the rest of genetic backgrounds, it increased with the temperature (Figure $2 \mathrm{G}$ and S, Table A1). NM1-NILs showed no response in most genetic backgrounds, except for GB2, in which a negative oleic

( acid response was observed. Despite this decrease, the oleic acid content was higher than $907 \mathrm{~g} \mathrm{~kg}^{-1}$. The slope of the relationships between the oleic acid and the temperature differed significantly between NILs carrying different mutations on the same genetic background $(p<0.05)$, except for the GB3 and GBH $(p>0.05)$.

Linoleic acid content decreased as temperature increased in all genetic backgrounds from both groups f NILs $(p<0.05)$ (Figure $2 \mathrm{H}, \mathrm{L}, \mathrm{P}$ and T, Table A1). The only exception was observed in NM1-1 genotype, in which a null response was observed.

Palmitic acid increased with temperature in all genetic backgrounds of all NILs $(p<0.05)$, except in GB1, in which it remained stable in both groups. Stearic acid increased only in GB2 $(p<0.05)$, remaining stable in the other genotypes (Figure 2, Table A1). Arachidic acid content did not respond to the temperature in any genetic background carrying the $P$ mutation, while a genetic background effect in NM1-NILs was observed, obtaining variable responses (data not shown).

This article is protected by copyright. All rights reserved. 


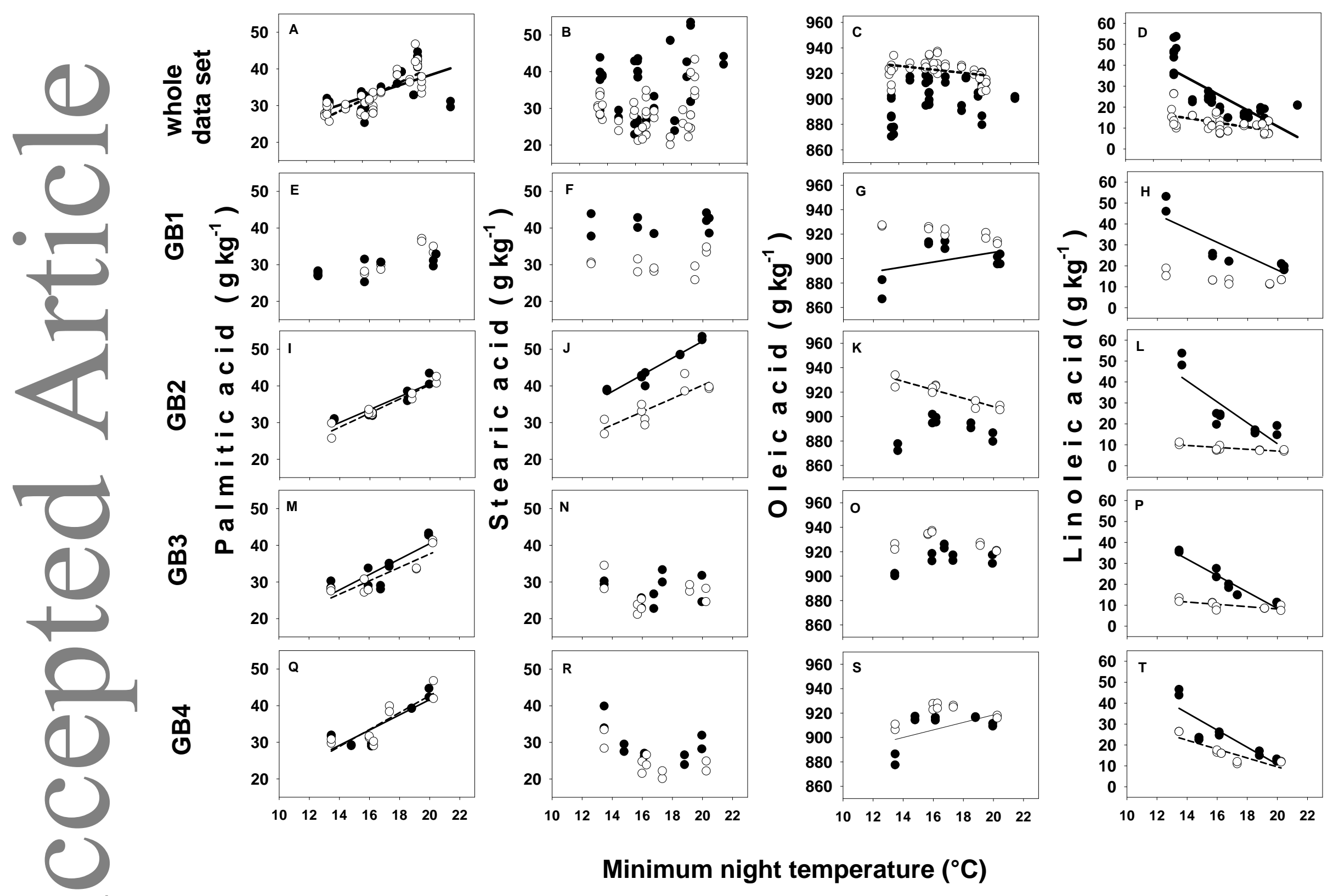

sure 2. Relationships between palmitic, stearic, oleic and linoleic acid contents and the MNT during 100-300 ddaf in $P$ and NM1-NILs grouping (lata from the four genetic backgrounds NILs (A-D) and the individual genetic backgrounds (GB1: E-H; GB2: I-L, GB3; M-P and GB4: Q-T). Filled crrces and solid lines correspond to the P-NILs. Empty circles and dashed lines correspond to the NM1-NILs.

This article is protected by copyright. All rights reserved. 


\section{Relationship between fatty acids}

Significant negative linoleic:oleic ratio was observed when P-NILs were analyzed altogether, while no relationship between these fatty acids was registered in NM1-NIL group. Genetic background effect was registered in the linoleic:oleic ratio in both groups of NILs. Different response patterns were observed when NIL pairs were compared with each other (Table 5).

Genetic background effect was also registered in the relationships between saturated and oleic acid contents (Table 5). P-NILs did not show significant relationship between palmitic:oleic, unlike in most NM1-NILs in which an inverse relationship between them was registered (Table 5). Stearic:oleic were inversely related in all NM1-NILs as well as in the GB4 genetic background of P-NILs.

Genetic background also affected the palmitic:linoleic and the stearic:linoleic relationships.

Palmitic acid was inversely related to linoleic acid content in P-3, NM1-2 and NM1-4 NILs

(Table 5). Stearic acid was inversely related to linoleic acid content in P-4 and NM1-2 NILs, and directly related in NM1-4 NIL (Table 5).

Table 5. Regression coefficient $\left(r^{2}\right)$, slope $\left(\mathrm{g} \mathrm{kg}^{-1} \mathrm{FAa} / \mathrm{g} \mathrm{kg}^{-1} \mathrm{FAb}\right)$ and $\mathrm{p}$-value of the adjusted functions of the relationships between L:O, P:O, S:O, P:L and S:L for the whole data set and each genetic background separately of the $P$ and NM1-NIL pairwise.

\begin{tabular}{|c|c|c|c|c|c|c|c|c|c|c|}
\hline & \multicolumn{10}{|c|}{ LINOLEIC:OLEIC } \\
\hline NILs & $\begin{array}{l}\text { Whole } \\
\text { data }\end{array}$ & $P-1$ & P-2 & P-3 & $P-4$ & $\begin{array}{c}\text { Whole } \\
\text { data }\end{array}$ & $\begin{array}{c}\text { NM1- } \\
1\end{array}$ & NM1-2 & $\begin{array}{c}\text { NM1- } \\
3\end{array}$ & $\begin{array}{c}\text { NM1- } \\
4\end{array}$ \\
\hline$r^{2}$ & 0.46 & 0.89 & 0.45 & - & 0.73 & - & - & 0.44 & - & 0.46 \\
\hline Slope & -0.85 & -0.88 & -0.48 & - & -1.01 & - & - & 4.88 & - & -0.89 \\
\hline $\begin{array}{l}p- \\
\text { value }\end{array}$ & $\begin{array}{c}p<0.000 \\
1\end{array}$ & $\begin{array}{c}<0.000 \\
1\end{array}$ & $\begin{array}{c}0.03 \\
3 \\
\end{array}$ & $\begin{array}{c}0.05 \\
5 \\
\end{array}$ & 0.002 & $p=0.21$ & 0.575 & 0.037 & 0.96 & 0.03 \\
\hline & \multicolumn{10}{|c|}{ PALMITIC:OLEIC } \\
\hline NILs & $\begin{array}{l}\text { Whole } \\
\text { data }\end{array}$ & $P-1$ & P-2 & P-3 & $\mathrm{P}-4$ & $\begin{array}{c}\text { Whole } \\
\text { data }\end{array}$ & $\begin{array}{c}\text { NM1- } \\
1\end{array}$ & NM1-2 & $\begin{array}{c}\text { NM1- } \\
3\end{array}$ & $\begin{array}{c}\text { NM1- } \\
4\end{array}$ \\
\hline$r^{2}$ & - & - & - & - & - & 0.30 & 0.47 & 0.91 & 0.40 & - \\
\hline Slope & - & - & - & - & - & -0.81 & -1.39 & -1.79 & -0.83 & - \\
\hline $\begin{array}{l}p- \\
\text { value }\end{array}$ & 0.75 & 0.067 & 0.67 & 0.88 & 0.69 & $p=0.003$ & 0.01 & $\begin{array}{c}<0.000 \\
1\end{array}$ & 0.031 & 0.956 \\
\hline
\end{tabular}

This article is protected by copyright. All rights reserved. 


\begin{tabular}{|c|c|c|c|c|c|c|c|c|c|c|}
\hline \multirow[b]{2}{*}{ NILs } & \multicolumn{10}{|c|}{ STEARIC:OLEIC } \\
\hline & $\begin{array}{c}\text { Whole } \\
\text { data }\end{array}$ & $P-1$ & P-2 & P-3 & $\mathrm{P}-4$ & $\begin{array}{c}\text { Whole } \\
\text { data }\end{array}$ & $\begin{array}{c}\text { NM1- } \\
1\end{array}$ & NM1-2 & $\begin{array}{c}\text { NM1- } \\
3\end{array}$ & $\begin{array}{c}\text { NM1- } \\
4\end{array}$ \\
\hline$r^{2}$ & 0.55 & - & - & - & 0.84 & 0.50 & 0.36 & 0.93 & 0.40 & 0.48 \\
\hline Slope & -1.25 & - & - & - & -2.80 & -1.02 & -0.92 & -1.73 & -1.15 & -1.50 \\
\hline \multirow[t]{2}{*}{$\begin{array}{l}p- \\
\text { value }\end{array}$} & $\begin{array}{c}p<0.000 \\
1\end{array}$ & 0.392 & $\begin{array}{c}0.98 \\
5 \\
\end{array}$ & 0.11 & $\begin{array}{c}<0.000 \\
1 \\
\end{array}$ & $\begin{array}{c}p<0.000 \\
1\end{array}$ & 0.038 & $\begin{array}{c}<0.000 \\
1 \\
\end{array}$ & 0.03 & 0.006 \\
\hline & \multicolumn{10}{|c|}{ PALMITIC:LINOLEIC } \\
\hline NILs & $\begin{array}{l}\text { Whole } \\
\text { data }\end{array}$ & P-1 & P-2 & P-3 & $\mathrm{P}-4$ & $\begin{array}{c}\text { Whole } \\
\text { data }\end{array}$ & $\begin{array}{c}\text { NM1- } \\
1\end{array}$ & NM1-2 & $\begin{array}{l}\text { NM1- } \\
3\end{array}$ & $\begin{array}{c}\text { NM1- } \\
4\end{array}$ \\
\hline$r^{2}$ & 0.30 & - & - & 0.40 & - & 0.12 & - & 0.45 & - & 0.40 \\
\hline Slope & -1.25 & - & - & -1.06 & - & -0.29 & - & -0.20 & - & -0.62 \\
\hline \multirow[t]{2}{*}{$\begin{array}{l}p- \\
\text { value }\end{array}$} & $p<0.001$ & 0.632 & $\begin{array}{c}0.05 \\
5 \\
\end{array}$ & $\begin{array}{c}0.03 \\
6 \\
\end{array}$ & 0.062 & $p=0.03$ & 0.897 & 0.02 & 0.195 & 0.028 \\
\hline & \multicolumn{10}{|c|}{ STEARIC:LINOLEIC } \\
\hline NILs & $\begin{array}{l}\text { Whole } \\
\text { data }\end{array}$ & $P-1$ & P-2 & P-3 & P-4 & $\begin{array}{c}\text { Whole } \\
\text { data }\end{array}$ & $\begin{array}{c}\text { NM1- } \\
1\end{array}$ & NM1-2 & $\begin{array}{l}\text { NM1- } \\
3\end{array}$ & $\begin{array}{c}\text { NM1- } \\
4\end{array}$ \\
\hline$r^{2}$ & - & - & - & - & 0.49 & - & - & 0.47 & - & 0.70 \\
\hline Slope & - & - & - & - & -3.89 & - & - & -0.19 & - & 1.23 \\
\hline $\begin{array}{l}p \text { - } \\
\text { value }\end{array}$ & 0.5 & 0.714 & $\begin{array}{c}0.82 \\
3 \\
\end{array}$ & $\begin{array}{c}0.82 \\
3 \\
\end{array}$ & 0.014 & 0.21 & 0.27 & 0.017 & 0.03 & 0.002 \\
\hline
\end{tabular}

L: linoleic; O: oleic; P: palmitic; S: stearic.

\section{DISCUSSION}

The present work expanded the analysis of high oleic trait and fatty acid composition in high oleic sunflower materials including NILs, bearing the NM1 mutation and NILs bearing its counterpart, the well-known Pervenets mutation $(P)$. Genotype characterization of the four elite genetic backgrounds evaluated was diverse enough in order to consider them as unrelated, covering a representative genetic diversity. Moreover, each pair of NILs carrying one or another allelic variant of the high oleic character, were close enough constituting true NILs. In this sense, working with inbred NILs provided the experimental advantage to characterize a particular phenotype compensating genetic interactions, like epistasis or pleiotropy. Thus the differences in the fatty acid composition can be attributed not only to the mutation $x$ environment interaction, but also to the genetic background. ${ }^{21,34}$ With the proposed experimental approach, genetic background effect on the stability of 
oilseed fatty acid composition from NILs carrying two different high oleic mutations (P or NM1) and its interaction with the environment was evaluated.

Genetic background effect was registered in the fatty acid composition when comparing P or NM1-NILs. According to results, the genetic variability in the oleic acid content reported by several authors in high oleic sunflower lines carrying the $\mathrm{P}$ mutation $^{35-38}$ and hybrids $^{22,24,39}$ may also be attributed to genetic background diversity. In the present work, the NM1-NIL group reached the highest oleic acid content when compared with P-NIL group with a minimum of $907 \mathrm{~g} \mathrm{~kg}^{-1}$. Thereby, NM1 mutation ensured the ultra-high oleic phenotype for all genetic backgrounds assayed. Besides, NM1-NILs exhibited the lowest $\mathrm{CV}$ indicating that these materials were less influenced by the genetic background than the P-NILs.

Genetic studies on different high oleic materials carrying the $P$ mutation have led to controversial results on the inheritance pattern of the high oleic trait due to variable expression of the mutation associated with different genetic factors affecting the oleic level. It was proposed, first, that the genetic background effect is related to a major gene with incomplete penetrance determined by genotypic epistatic factors of reversion; ${ }^{40}$ second, to a genetic control of the high oleic character determined by three loci: the fad21 gene, one suppressor or supole, and modifier genes. ${ }^{41,42}$ Thus, the suppressor of the mutation may mask the high oleic phenotype leading the presence of the $\mathrm{P}$ mutation as insufficient to induce the high oleic phenotype..$^{41,42}$ The epistatic factors may be attributed by other genes that depend on the genetic background which would interact with the mutation. ${ }^{43}$ Therefore, to maintain or increase the stability of oleic acid in high oleic $\mathrm{P}$ materials, factors related to the environment and/or the genetic background (that may modulate the suppression of the P mutation) should be taken into account.

As the high oleic phenotype in NM1-NILs is due to the effect of constitutive NM1 mutation on FAD2-1 protein ${ }^{10,44}$ suppressors would not be relevant in modulating the expression of 
the high oleic phenotype. That would explain why NM1-NILs consistently showed both, higher oleic acid content and higher fatty acid stability across genetic backgrounds and environments, compared to the respective P-NIL counterpart.

The mutation - genetic background interaction explained more of the oleic acid variation in P-NILs than in NM1-NILs. Particularly, the GB3 from both groups of NILs had shown the highest oleic acid content and the lowest saturated fatty acids, suggesting that this genetic background was the most favorable for the high oleic trait, independently of the type of mutation carried.

A genetic background effect was registered in the response of the fatty acids to the MNT. When the P-NIL group was analyzed as a single data set a non-significant relationship was observed between oleic acid and the MNT. Meanwhile, NM1-NIL group showed a mild although significant inverse relationship between both variables. Analyzing the group of P-NILs, P-1 showed an increase in oleic acid content as the MNT increased, being consistent with published data. ${ }^{14-17,19,21,22,24,34,45-49}$ The genotypes P-2, P-3 and P-4 showed a non-significant linear relationship between the oleic acid and the MNT, although a positive trend was observed.

In this sense, Martinez-Rivas et al. ${ }^{50}$ proposed that genes associated with the genetic background can interact with the high oleic character affecting the expression of the high oleic trait in sunflower materials bearing the $\mathrm{P}$ mutation. These results are consistent with those reported by Ferfuia et al. ${ }^{49}$ indicating that oleic content was modified by temperature in different high oleic inbred lines carrying the $\mathrm{P}$ mutation. Moreover, the variability reported previously in the response of oleic acid to the $\mathrm{MNT}^{22,24}$ would also depend on the genetic background.

In NM1-NILs, a null response was registered in most genetic backgrounds, except in NM1-2. Interestingly, an inverse relationship between the oleic acid and the MNT in the latter was observed. This unexpected trend could be explained by the increase in stearic 
acid, consistent with the relationship between the stearic and the oleic acid contents reported by Fernández-Moya et al.. ${ }^{51}$ However, the nature of this response pattern is still unknown.

As a general response pattern across genetic backgrounds for all NIL pairs evaluated, an increase in palmitic acid and a decrease in linoleic acid contents as temperature increased were observed. Moreover, this trend showed differences in the magnitude according to the genetic background or the high oleic mutation. This is in agreement with the general trend described by several authors working with different high oleic sunflower genotypes carrying Pervenets mutation. ${ }^{24,34,46,47,52,53}$

The positive response of palmitic acid to the MNT could be associated to the effect of the temperature over genes related to the genetic background that indirectly affected the KASII enzyme, increasing its activity ${ }^{42}$ and therefore contributing to the accumulation of palmitic acid.

The relationship between linoleic:oleic acids was compared taking the whole data set from P- and NM1-NILs across environments. Thus, P-NILs showed a negative relationship between them, unlike the NM1-NILs that presented a non-significant relationship. However, genetic background effect was registered in the linoleic:oleic ratio. In this sense, Joksimovic et al. ${ }^{54}$ proposed that this relationship is genetically controlled and it is also heavily influenced by the environment, mainly by the temperature. Additive gene action is more important for the oleic acid than non-additive gene action. Conversely, non-additive gene action, like epistasis, is more important for the inheritance of linoleic acid. ${ }^{54}$ Although this factor was not measured, the genetic background effect registered in the studied NILs, would highlight the genetic control over this relationship.

Furthermore, when P or NM1 mutations are present, the residual desaturation of oleic to linoleic acid could be due to the expression of the minor genes related to the genetic background, responsible for the basal temperature-independent enzyme activity, or other 
genes associated to the genetic background. The number of genes involved in the high oleic character expression and the genetic background from which they come, might regulate the genotype-environment interaction. ${ }^{55}$ In addition to the fad2-1 gene, two more isoform genes are present in sunflower: fad2-2 and fad2-3. While fad2-1 is seed specific and strongly expressed in developing seeds, fad2-2 and -3 are weakly expressed in developing seeds. ${ }^{50}$ However, the low content of oleic acid desaturated to linoleic acid, might depend in some extent to these minor genes than to the inhibited FAD2-1 enzyme..$^{50,56}$

The relationship between saturated fatty acids and the oleic or linoleic acid differed not only between P and NM1-NILs, but also between genetic backgrounds. The differences registered in these relationships exhibited in some P- or NM1-NILs could be explained, on one hand, by the positive effect of temperature over some of the enzymes of the FAS II complex or some of the SAD isoenzyme. Pérez-Vich et al. ${ }^{57}$ reported that genes codifying for the palmitic and the oleic acid traits are independently inherited. As in the present work, they described an inverse relationship between the palmitic and the oleic or linoleic acid in high oleic and high palmitic/ high oleic sunflower genotypes. In this sense, this particular relationships could be attributed to factors different to mutations on fad2-1 themselves, associated to the genetic background that can be affected by the temperature ${ }^{35,42,58}$ modifying also the response at level of fatty acid profile when different genetic backgrounds are compared.

\section{CONCLUSIONS}

This work presented new evidence about the effect of genetic background on fatty acid composition. Specifically it unveiled the behavior of the high oleic trait in a set of NILs carrying two different high oleic mutations, Pervenets and NM1. A genetic background effect was found in both NIL groups. However, in NM1 materials (compared to $P$ 
materials) the level and stability of oleic acid content increased across environments, independently of the genetic background. When selecting stable and ultra-high oleic genotypes, genetic background determined a null or low dependence in NILs carrying the NM1 mutation. Thus, this mutation is the best choice to develop ultra-high oleic sunflowers, which are stable across environments and genetic backgrounds, making the agronomical production of high oleic quality oils more efficient and predictable due to the stability of the trait.

\section{ACKNOWLEDGEMENTS}

Dr. Constanza Alberio holds a scholarship from CONICET, Argentina. This research was supported by INTA (PNCYO1127042), CONICET (PIP0541) and Universidad Nacional de Mar del Plata (AGR522/17). Authors wish to thank Luis Méndez for his technical assistance.

\section{REFERENCES}

1. Vanozzi GP, The perspectives of use of high oleic sunflower for oleochemistry and energy raws. Helia 29: 1-24 (2006).

2. Garcés R, Martínez-Force E, Salas JJ and Venegas-Calerón M, Current advances in sunflower oil and its applications. Lipid Technology 21: 79-82 (2009).

3. Di Marco A, Pan L and Añón MC, Ultra-high oleic sunflower oil. Physicochemical characterization. World Congress of Oil and Fats and $31^{\text {st }}$ International Society for Fats Research Lectureship Series, 31 Oct-4 Nov 2015, Rosario, Argentina (2015).

4. Pan L, Ultra-high oleic sunflower oil. $2^{\text {nd }}$ High Oleic Congress, 2-4 Sep 2015, Paris (2015).

5. Lukens LN and Doebley J, Epistatic and environmental interactions for quantitative trait loci involved in maize evolution. Genet Res 74: 291-302 (1999). 
6. Fernández-Martínez JM, Mancha M, Osorio J and Garcés R, Sunflower mutant containing high levels of palmitic acid in high oleic background. Euphytica 97: 113116 (1997).

7. Tanksley DS and Nelson CJ, Advanced backcross QTL analysis: A method for the simultaneous discovery and transfer of valuable QTL from unadapted germplasm into elite breeding lines. Theor Appl Genet 92: 191-203 (1996).

8. Guo P, Bai G, Carver B, Li R, Bernardo A and Baum M, Transcriptional analysis between two wheat near isogenic lines contrasting in aluminum tolerance under aluminum stress. Mol Genet Genomics 277: 1-12 (2007).

9. Keurentjes JJB, Bentsink L, Alonso-Blanco C, Hanhart CJ, Blankestijn-De Vries H, Effgen S, Vreugdenhil D and Koornneef M, Development of a near-isogenic line population of Arabidopsis thaliana and comparison of mapping power with a recombinant inbred line population. Genetics 175: 891-905 (2007).

10. Zambelli A, León A and Garcés R, Mutagenesis in sunflower, in Sunflower Oilseed Chemistry, Production, Processing and Utilization, ed. by Martínez-Force E, Dunford NT, Salas JJ. AOCS Monograph Series on Oilseeds, Volume 7 AOCS Press, Urbana, IL, pp. 27-52 (2015).

11. Canvin DT, The effect of temperature on the oil content and fatty acid composition of the oils from several oil seed crops. Can J Botany 43: 63-69 (1965).

12. Rochester CP and Silver JG, Unsaturated fatty acid synthesis in sunflower (Helianthus annuus L) seeds in response to night temperature. Plant Cell Rep 2(5): 229-231 (1983).

13. Lajara JR, Diaz $U$ and Quidiello RD, Definite influence of location and climatic conditions on the fatty acid composition of sunflower seed oil. J Am Oil Chem Soc 67: 618-623 (1990). 
14. Martínez-Force E, Álvarez-Ortega $R$, Cantisán $S$ and Garcés $R$, Fatty acid composition in developing high saturated sunflower (Helianthus annuus) seeds: maturation changes and temperature effect. J Agr Food Chem 46: 3577-3582 (1998).

15. Izquierdo N, Aguirrezábal L, Andrade F and Pereyra V, Night temperature affects fatty acid composition in sunflower oil depending on the hybrid and the phonological stage. Field Crop Res 77: 115-126 (2002).

16. Rondanini D, Savin R and Hall AJ, Dynamics of fruit growth and oil quality of sunflower (Helianthus annuus L) exposed to brief intervals of high temperature during grain filling. Field Crop Res 83: 79-90 (2003).

17. Izquierdo N, Aguirrezábal LAN, Andrade FH and Cantarero MG, Modeling the response of fatty acid composition to temperature in a traditional sunflower hybrid. Agron J 98: 451-461 (2006).

18. Rondanini D, Mantese A, Savin R and Hall AJ, Responses of sunflower yield and grain quality to alternating day/night high temperature regimes during grain filling: Effects of timing, duration and intensity of exposure to stress. Field Crop Res 96: 48-62 (2006).

19. Grunvald AK, de Carvalho CGP, Leite RS, Mandarino JMG, de Bastos-Andrade CA, Amabile RF and Godinho VDPC, Influence of temperature on the fatty acid composition of the oil from sunflower genotypes grown in tropical regions. J Am Oil Chem Soc 90: 545-553 (2013).

20. Izquierdo NG, Aguirrezábal, LAN, Martínez-Force E, Garcés R, Paccapelo V, Andrade F and Zambelli A, Effect of growth temperature on the high stearic and high stearic-high oleic sunflower traits. Crop Pasture Sci 64: 18-25 (2013).

This article is protected by copyright. All rights reserved. 
21. Van Der Merwe R, Labuschagne MT, Herselman L and Hugo A, Stability of seed oil quality traits in high and mid-oleic acid sunflower hybrids. Euphytica 193: 157-168 (2013).

22. Angeloni P, Echarte MM, Irujo GP, Izquierdo NG and Aguirrezábal L, Fatty acid composition of high oleic sunflower hybrids in a changing environment. Field Crop Res 202: 146-157 (2017).

23. Alberio C, Izquierdo NG, Galella T, Zuil S, Reid R, Zambelli A and Aguirrezábal LAN. A new sunflower high oleic mutation confers stable oil grain fatty acid composition across environments. Eur J Agron 73: 25-33 (2016).

24. Izquierdo N and Aguirrezábal LAN, Genetic variability in the response of fatty acid composition to night temperature during grain filling in sunflower. Field Crop Res 106: 116-125 (2008).

25. Schneiter AA and Miller JF, Description of Sunflower Growth Stages. Crop Sci 21: 901-903 (1981)

26. Farizo CL, Pereyra VR, Cardinali F and Orioli G, Determination of physiological and harvest maturity in sunflower, in Proc. Tenth International Sunflower Conf., 10th, Surfers Paradise, QLD, Australia, 14-18 Mar 1982. Sunflower Assoc., Paris, pp. 42-44 (1982).

27. Walkley A and Black IA, An Examination of Degtjareff method for determining soil organic matter and a proposed modification of the chromic acid titration method. Soil Sci 37:29-37 (1934).

28. Echeverría HE, San Martín NF and Bergonzi R, Métodos rápidos de estimación de nitrógeno potencialmente mineralizable en suelos. Ciencia del Suelo 18: 9-16 (2000).

29. Bray RR and Kurtz L, Determination of total organic and available forms of phosphorus in soils. Soil Sci 59: 39-45 (1945). 
30. Díaz-Zorita M, Girasol, in Fertilidad de suelos y fertilización de cultivos, ed. by Echeverría H and García FO. INTA ediciones, 2da. Edición, Buenos Aires. pp. 509-524 (2014).

31. Ruiz-López N, Martínez-Force E and Garcés R, Sequential one-step extraction and analysis of triacylglycerols and fatty acids in plant tissues. Anal Biochem 317: 247254 (2003).

32. InfoStat, Manual de usuario, Grupo InfoStat, FCA, Universidad Nacional de Córdoba, Argentina, (2008).

33. Kiniry JR, Blanchet R, Williams JR, Texier V, Jones CA and Cabelguenne $M$, Sunflower simulation using the EPIC and ALMANAC models. Field Crop Res 30: 403-423 (1992)

34. Salera E and Baldini M, Performance of high and low oleic acid hybrids of sunflower under different environmental conditions, note 2 Helia 21:55-67 (1998).

35. Fernández-Martínez J, Muñoz J and Gómez-Arnau J, Performance of near-isogenic high and low oleic acid hybrids of sunflower. Crop Sci 33: 1158-1163 (1993).

36. Lacombe S, Léger S, Kaan F and Bervillé A, Inheritance of oleic acid content in F2 and a population of recombinant inbred lines segregating for the high oleic trait in sunflower. Helia 25: 85-94 (2002).

37. Varès D, Lacombe S, Griveau Y, Bervillé A and Kaan F, Inheritance of oleic acid content of $\mathrm{f} 1$ seed in a complete diallel cross between seven sunflower lines. Helia 25: 105-112 (2002).

38. Demurin Y, Up-to-date results on biochemical genetics of sunflower in VNIIMK. Helia 26: 137-142 (2003).

39. Škorić D, Jocić S, Lečić $N$ and Sakač Z, Development of sunflower hybrids with different oil quality. Helia 30: 205-212 (2007). 
40. Demurin $Y$ and Borisenko O, Genetic collection of oleic acid content in sunflower seed oil. Helia 34: 69-74 (2011).

41. Lacombe S, Kaan F, Léger S and Bervillé A, An oleate desaturase and a suppressor loci direct high oleic acid content of sunflower (Helianthus annuus L) oil in the Pervenets mutant. Life Sci 324: 839-845 (2001).

42. Lacombe S, Kaan F, Griveau Y and Bervillé A, The Pervenets high oleic mutation: methodological studies. Helia 27: 41-54 (2004).

43. Demurin $Y$ and Skorić D. Unstable expression of Ol gene for high oleic acid content in sunflower seeds, in Proceedings of the 14th International Sunflower Conference I, Beiging/Shenyang, China pp. 12-20 (1996).

44. León AJ, Zambelli AD, Reid RJ, Morata MM and Kaspar M, Nucleotide sequences mutated by insertion that encode a truncated oleate desaturase protein, proteins, methods and uses. WIPO Patent WO 2013/004281 A1, January 10, (2013).

45. Lagravere T, Lacombe S, Surel O, Kleiber D, Berville A and Dayde J, Oil composition and accumulation of fatty acids in new oleic sunflower (Helianthus annuus L) hybrids, in Proceedings of the $15^{\text {th }}$ International Sunflower Conference, Jun 12-15 2000, A25, Toulouse (2000).

46. Lagravere T, Champoveliver L, Lacombe S, Kleiber D, Berville A and Dayde J, Effects of temperature variations on fatty acid composition in oleic acid sunflower oil (Helianthus annuus L) hybrids, in Proceedings of the $15^{\text {th }}$ International Sunflower Conference, Jun 12-15 2000, A68, Toulouse (2000).

47. Triboï-Blondel A, Bonnemoy B, Falcimagne R, Martignac M, Messaoud J, Philippon J and Vear F, The effect of temperature from flowering to maturity on seed composition of high oleic sunflower inbreeds and mid oleic hybrids, in Proceedings of the $15^{\text {th }}$ International Sunflower Conference, Jun 12-15 2000, A67, Toulouse (2000).

This article is protected by copyright. All rights reserved. 
48. Pleite R, Rondanini D, Garcés R and Martínez-Force E, Day-night variation in fatty acids and lipids biosynthesis in sunflower seeds. Crop Sci 48(5): 1952-1957 (2008).

49. Ferfuia C, Turi M and Vannozzi GP, Variability of Seed Fatty Acid Composition to Growing Degree-Days in High Oleic Acid Sunflower Genotypes. Helia 38: 61-78 (2015).

50. Martínez-Rivas JM, Sperling $P$, Wilfried $L$ and Heinz E, Spatial and temporal regulation of three different microsomal oleate desaturase genes (FAD2) from normal-type and high-oleic varieties of sunflower (Helianthus annuus L). Mol Breeding 8: 159-168 (2001).

51. Fernández-Moya V, Martínez-Force E and Garcés, R, Temperature-related nonhomogeneous fatty acid desaturation in sunflower (Helianthus annuus L.) seeds. Planta 216: 834-840 (2003).

52. Champolivier, $L$ and Merrien, A, Evolution de la teneur en huile et de sa composition en acides gras chez deux variétés de tournesol (oléique ou non) sous l'effet de températures différentes pendant la maturation des graines. OCL 3: 140-144 (1996).

53. Izquierdo NG, Martínez-Force E, Garcés R, Aguirrezábal LA, Zambelli A and Reid R, Temperature effect on triacylglycerol species in seed oil from high stearic sunflower lines with different genetic backgrounds. J Sci Food Agric 96: 4367-4376 (2016).

54. Joksimović, J, Atlagić, J, Marinković, R and Jovanović, D, Genetic control of oleic and linoleic acid contents in sunflower Helia 29: 33-40 (2006).

55. Fernández-Martínez JM, Velasco $L$ and Pérez-Vich $B$, Progress in the genetic modification of sunflower oil quality, in Proceedings of the $16^{\text {th }}$ International Sunflower Conference, 29 Ago-2 Sep 2004, Fargo, ND, pp. 1-15 (2004). 
56. Garcés R, Sarmiento $\mathrm{C}$ and Mancha M, Temperature regulation of oleate desaturase in sunflower (Heliantus annuus L.) seeds. Planta 186: 461-465 (1992).

57. Pérez-Vich B, Garces R and Fernández-Martínez JM, Inheritance of high palmitic acid content in the sunflower mutant CAS-12 and its relationship with high oleic content. Plant Breeding 121: 49-56 (2002).

58. Velasco L, Peréz-Vich B and Fernández-Martinez JM, Inheritance of oleic acid content under controlled environment, in Proceedings of the $15^{\text {th }}$ International Sunflower Conference, Jun 12-15 2000, A31, Toulouse (2000).

This article is protected by copyright. All rights reserved. 